\title{
Von Hippel Award Presented to John W. Cahn
}

\begin{abstract}
Editor's Note: John W. Cahn was the recipient of the 1985 Von Hippel Award, presented Monday evening, December 2 at the Fall Meeting. The following is an abridged transcript of comments made about Dr. Cahn's achievements by MRS Awards Committee Chair Woody White and Professor David Turnbull, Harvard University.
\end{abstract}

C. W. White: The Von Hippel Award is the highest award given by the Materials Research Society, and it has come to be the most prestigious award for career achievements in materials science. The Von Hippel Award is intended to honor members of the scientific profession whose materials research achievements are exemplary, not only for excellence and importance, but also for the demonstrated application of an interdisciplinary approach to materials research. The award is presented annually to a living scientist whose career exemplifies originality, brilliance of intellect, and diligence of purpose; who adheres to the strictest ethical standards; and whose vision and research accomplishments transcend the conventional disciplines as does the science of materials itself. The Von Hippel Award is named in honor of Professor Arthur Von Hippel, emeritus professor of MIT, who was also its first recipient in 1976.

It is my pleasure to present the 1985 Von Hippel Award to Dr. John Cahn from the National Bureau of Standards. Dr. Cahn's professional career extends over three decades at General Electric, MIT and most recently the National Bureau of Standards. During this time he has made pioneering contributions in many areas associated with materials research. He is acknowledged to be one of the intellectual giants of our time in materials science.

Since its inception, the Von Hippel Award has been given to a very distinguished group of individuals whose contributions represent the very finest in the fields of materials research, and the addition of the name John Cahn to that list will add stature and prestige to the award itself.

\section{CITATION:}

"To John Cahn for pioneering research in a broad spectrum of materials science, especially on phase separation in solids, including spinodal decomposition, on thermodynamic properties of interfaces, on thermodynamics of stress solids, on solid trapping during rapid solidification and most recently on quasi-crystals exhibiting icosahedral symmetry."

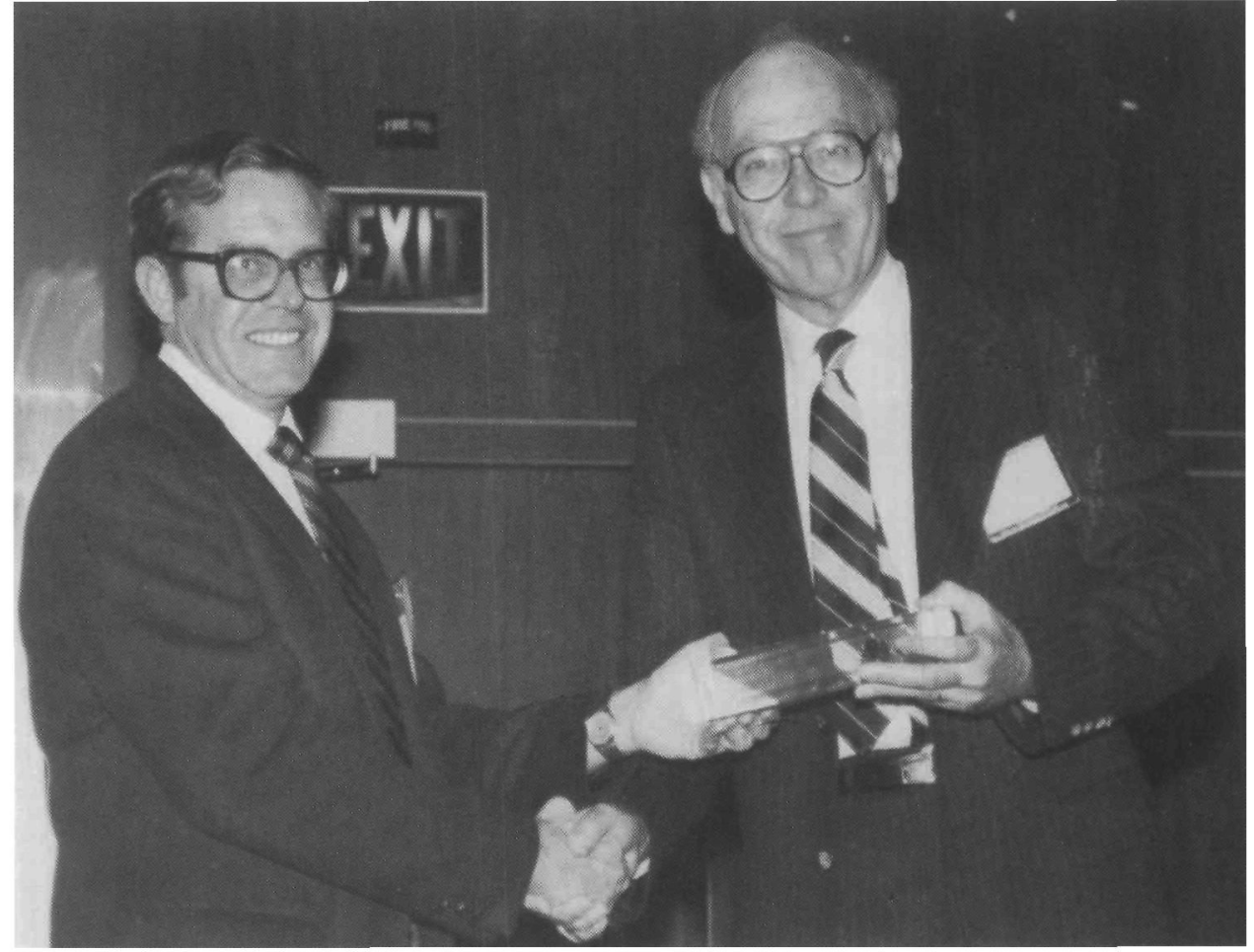

John W. Cahn (right) receives 1985 Von Hippel Award from Awards Committee Chair Woody White. The ceremony was held Monday evening, December 2, during the MRS Fall Meeting.

We are privileged to have with us tonight a man who has been very familiar with Dr. Cahn and his contributions to materials research, David Turnbull of Harvard University, who has been closely associated with Dr. Cahn for more than 30 years. Prof. Turnbull will now summarize some of Cahn's monumental achievements and try to put them into perspective for you.

D. Turnbull: I will only reiterate and perhaps elaborate a bit on the remarks that were presented in the MRS BULLETIN about John Cahn's career. I would like to start by suggesting that perhaps the core element in materials science, to borrow a term from one of the Harvard deans, is classical thermodynamics and the principles of the architecture of condensed phases. I think that John Cahn by his achievements has reflected a tremendous mastery and a deep understanding of these core elements of materials science that cut across all the various disciplines of materials science: ceramics, metallurgy, solid state physics, solid state chemistry, and so on.

The one way to measure the achievements of an individual is in terms of what his achievements - his research - has contributed to science. We have various "house- hold" words in materials science, that have become familiar as a result of John's achievements and they, to some extent, summarize the progression of what he's done. These terms are, of course, spinodal, the CahnHilliard equation for free energy, the Cahn diffusion equation. These terms are now familiar in the ceramics literature and the metallurgy literature, and they even find their way frequently into the lofty precincts of the Physical Review Letters.

John has been a tremendous admirer of Willard Gibbs and, justifiably, he has been considered to be almost a latter-day Gibbs in the power and rigor of his thought and in the magnitude of his achievements.

An award is not so much to reward the recipient as it is something that basically honors the award. We might also mention that the award also serves the purpose to call attention to significant landmark contributions. I know that I speak for Prof. Von Hippel and the other recipients of this award that we are very pleased with the selection of John Cahn as recipient of the award, and we feel that the luster of the award is certainly upheld by the selection.

Editor's Note: Prof. Turnbull received the Von Hippel Award in 1979. 